\title{
Deteksi Bot Spammer pada Twitter Berbasis Sentiment Analysis dan Time Interval Entropy
}

\author{
Christian Sri Kusuma Aditya1, Mamluatul Hani’ah², Alif Akbar Fitrawan³, Agus Zainal Arifin', Diana \\ Purwitasari $^{5}$ \\ Jurusan Teknik Informatika, Fakultas Teknologi Informasi, Institut Teknologi Sepuluh Nopember \\ Jl. Teknik Kimia, Gedung Teknik Informatika, Kampus ITS Sukolilo, Surabaya 60111, Jawa Timur \\ E-mail: ${ }^{1}$ christian.s.k.aditya@ gmail.com, ${ }^{2}$ mamluatul14@mhs.if.its.ac.id, ${ }^{3}$ alif14@mhs.if.its.ac.id, \\ ${ }^{4}$ agusza@cs.its.ac.id, ${ }^{5}$ diana@if.its.ac.id
}

Masuk: 22 Desember 2015; Direvisi: 29 Januari 2016; Diterima: 3 Februari 2016

\begin{abstract}
Spam is an abuse of messaging undesired by recipients. Those who send spam are called spammers. Popularity of Twitter has attracted spammers to use it as a means to disseminate spam messages. The spams are characterized by a neutral emotional sentiment or no particular users' preference perspective. In addition, the regularity of tweeting behavior periodically shows automation performed by bot. This study proposes a new method to differentiate between bot spammer and legitimate user accounts by integrating the sentiment analysis (SA) based on emotions and time interval entropy (TIE). The combination of knowledge-based and machine learning-based were used to classify tweets with positive, negative and neutral sentiments. Furthermore, the collection of timestamp is used to calculate the time interval entropy of each account. The results show that the precision and recall of the proposed method reach up to $83 \%$ and $91 \%$. This proves that the merging SA and TIE can optimize overall system performance in detecting Bot Spammer.
\end{abstract}

Keywords: bot spammer, twitter, sentiment analysis, polarity, entropy

\begin{abstract}
Abstrak. Spam merupakan penyalahgunaan pengiriman pesan tanpa dikehendaki oleh penerimanya, orang yang mengirimkan spam disebut spammer. Ketenaran Twitter mengundang spammer untuk menggunakannya sebagai sarana menyebarluaskan pesan spam. Karakteristik dari tweet yang dikategorikan spam memiliki sentimen emosi netral atau tidak ada preferensi tertentu terhadap suatu perspektif dari user yang memposting tweet. Selain itu keteraturan waktu perilaku saat memposting tweet secara periodik menunjukkan otomatisasi yang dilakukan bot. Pada penelitian ini diusulkan metode baru untuk mendeteksi antara bot spammer dan legitimate user dengan mengintegrasikan sentimen analysis berdasarkan emosi dan time interval entropy. Pendekatan gabungan knowledgebased dan machine learning-based digunakan untuk mengklasifikasi tweet yang memiliki sentimen positif, negatif dan tweet netral. Selanjutnya kumpulan timestamp digunakan untuk menghitung time interval entropy dari tiap akun. Hasil percobaan menunjukan bahwa precision dan recall dari metode yang diusulkan mencapai $83 \%$ dan $91 \%$. Hal ini membuktikan penggabungan Sentiment Analysis (SA) dan Time Interval Entropy (TIE) dapat mengoptimalkan performa sistem secara keseluruhan dalam mendeteksi Bot Spammer.
\end{abstract}

Kata Kunci: bot spammer, twitter, sentiment analysis, polarity, entropy

\section{Pendahuluan}

Situs microblogging telah menjadi alat komunikasi yang sangat populer di kalangan pengguna internet. Setiap hari jutaan pesan muncul di situs web populer yang menyediakan layanan microblogging seperti Twitter, Tumblr, dan Facebook. Twitter adalah sebuah situs web yang dimiliki dan dioperasikan oleh Twitter Inc., menawarkan jaringan sosial berupa microblogging sehingga memungkinkan penggunanya untuk mengirim dan membaca pesan di Twitter. Tidak seperti Facebook, LinkedIn, dan MySpace, Twitter merupakan sebuah jejaring sosial yang dapat digambarkan sebagai sebuah graph berarah yang berarti bahwa pengguna 
dapat mengikuti pengguna lain, namun pengguna kedua tidak diperlukan untuk mengikutinya kembali. Twitter mengizinkan penggunanya untuk membaca dan menulis pesan singkat yang dibatasi maksimal 140 karakter. Pesan singkat yang sering disebut tweet tersebut kebanyakan bersifat publik dan dapat dilihat oleh pengguna lain. Menurut penelitian Takhteyev, dkk. (2012) hanya terdapat sekitar 10\% dari pengguna Twitter yang memproteksi tweet mereka.

Twitter dengan pengguna lebih dari 500 juta dan 400 juta tweet perhari memungkinkan pengguna untuk berbagi pesan menggunakan tweet. Pengguna Twitter menulis tentang kehidupan mereka, berbagi opini tentang berbagai topik dan membahas isu-isu yang terjadi pada saat ini. Aksesibilitas dari berbagai platform yang mudah, pengguna internet cenderung untuk beralih dari blog atau milis ke layanan microblogging. Hal tersebut menyebabkan semakin banyak pengguna Twitter yang melakukan posting tentang suatu produk dan layanan yang mereka gunakan untuk mengekspresikan pandangan mereka. Twitter dapat menjadi sumber data pendapat dan sentimen masyarakat. Seiring dengan kepopuleran dan potensi dari Twitter di dunia internet menyebabkan para spammer mulai melirik untuk membanjiri pesan spam demi keuntungan pribadinya. Aktifitas spam dilakukan atas berbagai tujuan. Salah satunya adalah tujuan komersial berupa iklan dan promosi. Spam ini tidak memerlukan mailing list untuk mencapai para pelanggan-pelanggan yang diinginkan, oleh karena itu spam dikirimkan dengan biaya operasi yang sangat rendah. Spam bisa berisi pesan singkat atau menanam link saja yang sebagian besar tidak berfokus kepada materi posting yang sedang disajikan, namun jika dilakukan secara terus-menerus akan mengganggu pengguna yang menerima ataupun sekedar melintas. Dari aspek teknis, pesan yang dikirim sekaligus dan terus-menerus akan membutuhkan sumber daya (resource) yang sangat banyak, baik dari segi kemampuan server maupun bandwidth, hal ini dapat mengakibatkan beban server yang tinggi yang dapat mengakibatkan server down. Tak jarang pula pelaku menggunakan robot ataupun aplikasi yang secara otomatis mengirim pesan spam.

Pengguna Twitter diklasifikasikan menjadi beberapa kategori yaitu manusia (legitimate user), cyborg, dan bot. Fitur-fitur Twitter seperti waktu pengguna mengunggah tweet, tweet content, dan account properties adalah fitur yang dapat digunakan untuk mengidentifikasi manusia, cyborg, atau bot. Diantara fitur-fitur tersebut, waktu pengguna untuk mengunggah dapat digunakan untuk mencari interval entropy. Interval entropy ini dapat menghasilkan tingkat akurasi tinggi jika dibandingkan fitur tweet content dan account properties.

Program otomatisasi atau yang dikenal sebagai bot merupakan kependekan dari nama robot. Bot tidak membutuhkan campur tangan manusia dalam melakukan pekerjaan rutinitasnya setiap waktu. Bot spammer secara otomatis menghasilkan spam pada interval waktu tertentu menggunakan scheduler pekerjaan. Pengeloaan akun spam secara manual dapat menyebabkan biaya yang tinggi sehingga dengan digunakannya bot maka dapat mengurangi biaya. Dengan demikian spammer akan lebih mudah untuk menghasilkan pesan spam dalam jumlah yang banyak di Twitter. Selain untuk menghasilkan pesan dalam jumlah yang banyak beberapa bot diciptakan untuk menyebarkan pesan yang berbahaya (Heron, 2009).

Twitter sendiri memiliki mekanisme untuk penanganan spam dengan mengajak pengguna Twitter untuk melaporkan pesan spam dan akun yang terindikasi sebagai bot. Namun cara ini dinilai memiliki kelemahan apabila laporan pengguna Twitter yang dikumpulkan ternyata laporan palsu, kesalahan pelabelan akun legitimate sebagai spammer atau bot dapat menurunkan kredibilitas Twitter. Beberapa penelitian telah dilakukan mengenai otomatisasi (bot) dan deteksi spam, untuk membantu mengurangi munculnya spam khususnya di Twitter.

Penelitian yang dilakukan oleh Chu, dkk. (2012) dapat mengidentifikasi akun manusia, cyborg, atau bot dengan cara mengamati perbedaan kebiasan perilaku mengetweet, konten dari tweet, serta karakteristik akun seperti jumlah follower, following, dan retweet. Pada konten dari tweet dapat dilakukan deteksi emosi/sentimen emosi dengan menggunakan machine learning atau polaritas. Penelitian tentang polaritas (Lima, dkk., 2015) dan sentimen emosi (Mohammad, dkk., 2014) pada Twitter juga telah banyak dilakukan. Penelitian Lima, dkk. (2015) memperkenalkan framework PAFRA untuk mengklasifikasikan polaritas tweet terhadap suatu topik. 
Jika dilihat dari karakteristiknya, beberapa tweet yang masuk kategori spam sering kali di-posting secara otomatis dimana tweet diunggah secara teratur dalam waktu yang dekat. Selain itu tweet tersebut seringkali tidak memiliki ungkapan ekspresi, sedangkan legitimate user cenderung mem-posting tweet yang memiliki preferensi tertentu terhadap suatu perspektif dan ideologi yang memiliki ungkapan ekspresi pandangan ataupun opini. Sehingga untuk mendeteksi bot spammer pada twitter tidak cukup hanya dengan menggunakan time interval entropy untuk mendeteksi regularitas kebiasaan posting tweet, akan tetapi dibutuhkan metode yang dapat mendeteksi sebuah ungkapan ekspresi pada tweet.

Oleh karena itu, pada penelitian ini diusulkan metode baru untuk mendeteksi antara bot spammer dan legitimate user dengan mengintegrasikan Sentiment Analysis (SA) berdasarkan emosi dan Time Interval Entropy (TIE). Sentiment analysis (SA) digunakan untuk mendeteksi ungkapan ekspresi ataupun opini yang terkandung dalam tweet. Sentiment analysis (SA) pada penelitian ini menggunakan penggabungan metode knowledge-based dan machine learningbased untuk mendapatkan tweet netral atau yang tidak memiliki sentimen emosi dimana sering muncul pada tweet bertipe spam. Sedangkan TIE digunakan untuk menangkap keteraturan waktu mem-posting tweet yang menunjukkan tweet diunggah secara otomatis.

\section{Data dan Metode Penelitian}

\subsection{Data}

Data Tweet dalam penelitian ini diperoleh dengan memanfaatkan API yang disediakan oleh Twitter. Dengan memanfaatkan API tersebut dibangun sebuah aplikasi untuk mengambil data tweet dari Twitter kemudian disimpan ke dalam database. Total semua data yang didapat adalah 39 akun pengguna Twitter yang ditulis menggunakan Bahasa Indonesia. Terdapat sekitar 500 tweet untuk setiap akun. Selanjutnya setiap akun akan diklasifikasikan secara manual antara akun legitimate user dan akun bot spammer. Dari hasil klasifikasi secara manual didapat sebanyak 14 akun legitimate user dan 25 akun bot spammer. Jumlah data training set yang digunakan sebanyak 11.000 tweet dari 21 akun sedangkan untuk test set sebanyak 18 akun dengan masing-masing kurang lebih 500 tweet tiap akun.

Terdapat beberapa karakteristik yang digunakan untuk melakukan pelabelan manual akun bot spammer, karakteristik tersebut adalah sebagai berikut (Yang, dkk., 2011): (1) Spam yang berisi link aktif. Hal ini di lakukan untuk mempromosikan sebuah website dengan cara menautkan link aktif berupa URL. (2) Spam yang berisi promosi atau menawarkan produk tertentu. Spam ini masih berkaitan dengan jenis yang pertama, yaitu berisi link aktif yang menawarkan promosi produk tertentu. (3) Kesamaan tweet dengan tweet sebelumnya. Hal ini dilihat berdasarkan kumpulan tweet yang telah di-posting oleh pengguna Twitter, jika tiap tweet memiliki kesamaan konten atau kemiripan kemunculan kata yang digunakan maka akun tersebut dapat dikategorikan sebagai bot spammer. (4) Akun baru, Spammer biasanya selalu berganti-ganti akun Twitter. Usia dari sebuah akun dapat diketahui melalui informasi yang ada pada profil akun yang bersangkutan. (5) Spam seringkali memakai banyak hashtag. Hashtag memudahkan pencarian tweet, atau memperbesar peluang untuk menjadi trending topic (Verma \& Sofat, 2014).

\subsection{Metode}

Pada penelitian ini diusulkan metode baru untuk membedakan antara bot spammer dan legitimate user dengan mengintegrasikan sentiment analysis (SA) berdasarkan emosi dan time interval entropy (TIE). Skema dari usulan kontribusi metode dan proses keseluruhan sistem dapat dilihat pada Gambar 1. Langkah pertama adalah melakukan tahap preprocessing. Preprocessing terdiri dari empat langkah antara lain data cleaning, tokenizing, stopword removal dan stemming yang dilakukan secara berurutan (Miller, dkk., 2014). Data cleaning adalah membersihkan tweet dari tautan URL, mention, hashtag, dan simbol RT. Tokenizing digunakan untuk mempartisi tweet menjadi token atau kata. Stopword removal dilakukan dengan cara menghapus daftar kata yang dianggap kurang penting, daftar kata stopword diambil dari penelitian Tala (2003). Proses terakhir dari preprocessing adalah stemming yaitu mencari 
kata dasar dari tiap kata tweet menggunakan algortima yang diusulkan oleh Arifin \& Setiono (2002).

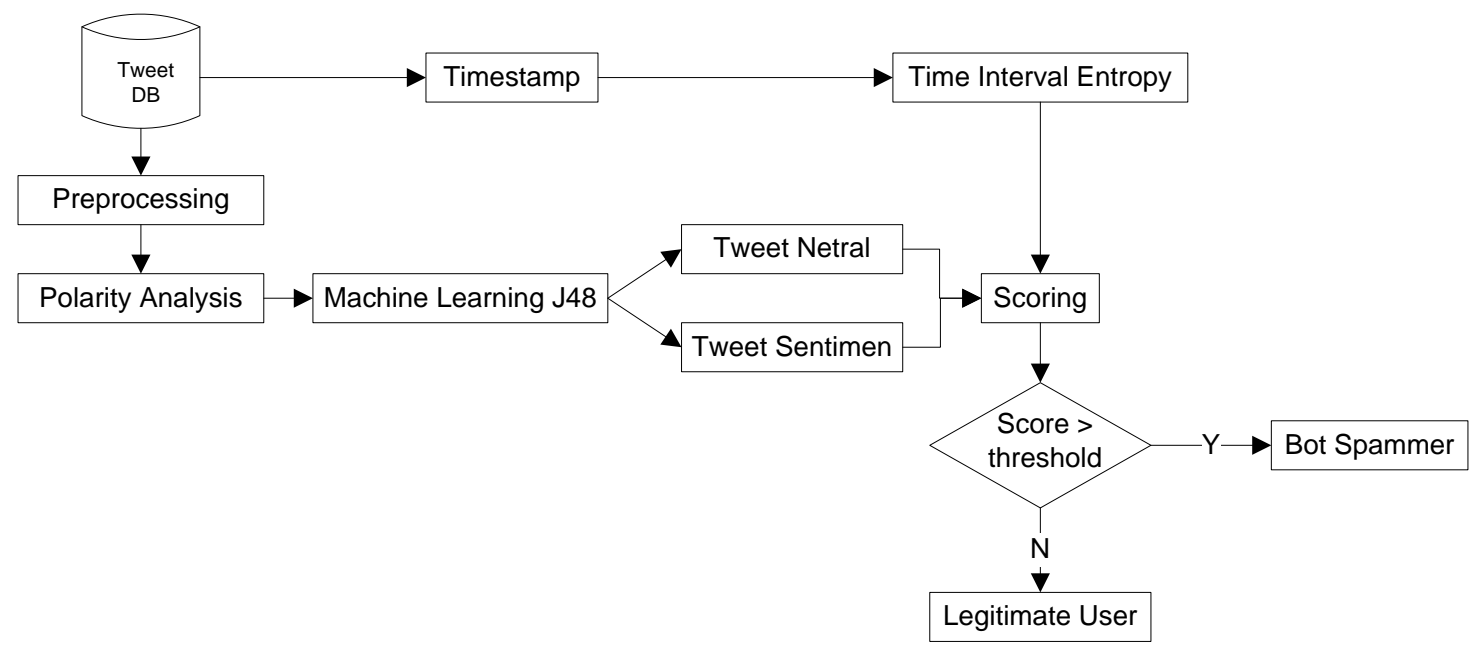

Gambar 1. Diagram Blok Metode yang Diusulkan

Setelah melakukan tahap awal pemrosesan teks berikutnya adalah mencari sentimen tweet untuk tiap akun. Sebuah sentimen pada dasarnya adalah ungkapan polaritas sebuah teks yang dilabelkan apakah itu berkonotasi positif, netral, dan negatif (Kontopoulos, dkk., 2013). Penentuan sentimen dapat dilakukan pada tingkatan yang berbeda: dokumen (Moraes, dkk., 2013), kalimat (Poria, dkk., 2014) dan kata atau atribut. Sentiment analysis atau opinion mining adalah studi komputasional dari opini-opini orang, sentimen dan emosi melalui entitas atau atribut yang dimiliki yang diekspresikan dalam bentuk teks (Liu, 2012). Pendekatan SA yang digunakan pada penelitian ini adalah dengan penggabungan metode Knowledge-based dan Machine learning-based.

Knowledge-based merupakan metode pendekatan SA yang menggunakan bantuan sebuah kamus atau dictionaries, seperti Linguistic Inquiry and Word Count (LIWC) (Tausczik \& Pennebaker, 2010) dan SentiWordnet (Esuli \& Sebastiani, 2006) yang sering digunakan pada domain teks Bahasa Inggris. Kamus dibentuk oleh kumpulan kata dan diklasifikasikan sesuai nilai polaritasnya. Misalnya, kata bahagia memiliki nilai +1 menunjukkan bahwa kata ini memiliki polaritas positif, atau sebaliknya, kata sedih memiliki nilai -1 menunjukkan polaritas negatif (Montejo-Ráez, dkk., 2014). Bentuk paling sederhana untuk mendapatkan polaritas dari teks adalah dengan menjumlahkan nilai sentimen dari semua kata-kata yang ada dalam teks dan menentukan polaritas yang dihasilkan (Lima, dkk., 2015). Melalui beberapa kali percobaan, ditentukan interval threshold untuk kategori netral adalah -1 sampai dengan 1, sedangkan nilai diatas +1 adalah sentimen positif dan nilai dibawah -1 adalah sentimen negatif. Berikut contoh dari posting tweet bersentimen netral dan yang bersentimen positif/negatif dapat dilihat pada Tabel 1.

Tabel 1. Polaritas tweet

\begin{tabular}{cl}
\hline Interval Polaritas & Tweet \\
\hline $\mathbf{0}$ & $\begin{array}{l}\text { Hai Kak, @alisya_monica, Follow @ InfoMakassarID yuk.. untuk dapat info paling } \\
\text { update seputar Makassar.., pasti di Folback! }\end{array}$ \\
hai kak, @ rudhybm, mau dapat info terbaru seputar peluang usaha? follow \\
@ InfousahaID ya.. Pasti di Folback! \\
hai kak,@ fahirafahi,Sudah Terbukti di 17 Negara Cara Belajar Bahasa Asing Tanpa \\
Kursus Info PIN:7D07C8E6 http://t.co/qEc2JHDSYH \\
RT @ tsuroiya: Makin hormat dan kagum sama Bu Susi. Perjalanan hidupnya luar Positif/Negatif \\
biasa dahsyat, tp cara dia bercerita santai dan rendah hati. \\
Turut berduka cita atas berpulangnya ananda Maulana (PTIIK-2013). :( Semoga amal \\
ibadahnya diterima olehNya... Aamiin \#fb
\end{tabular}


Pada penelitian ini daftar kata lexical database yang digunakan adalah daftar lexical dari penelitian $(\mathrm{Hu} \& \mathrm{Liu}, 2004)$. Daftar tersebut kemudian diterjemahkan dan dilakukan beberapa penyesuaian ke dalam Bahasa Indonesia. Total jumlah keseluruhan lexical berisi 3.535 kata dengan daftar jumlah kata sentimen positif sebanyak 1.126 dan jumlah kata sentimen negatif sebanyak 2.409. Contoh daftar kata yang digunakan untuk menentukan polaritas menggunakan pendekatan knowledge-based dapat dilihat pada Tabel 2.

Tabel 2. Contoh daftar kata lexical database

\begin{tabular}{llll}
\hline Kata Positif & Kata Negatif & Emoticon Positif & Emoticon Negatif \\
\hline adil, arif, alhamdulillah, bahagia, baik, & abai, aneh, apati, bahaya, benci, & $:-),:),=),: \mathrm{D}, \mathrm{o}:)$ & $:-\left(,:\left(,=\left(, ;\left(, \mathrm{T} \_\mathrm{T}\right.\right.\right.\right.$, -_- $^{-}$ \\
berkah, bersih, bijaksana, cepat, cerdas, & cemas, cela, dendam, erang, & & \\
damai, empati, fokus, gigih, hebat, inisiatif, & gagal, gila, hina, injak, jahat, keji, & \\
jujur, kagum, kuat, lancar, manis, nikmat, & korup, lambat, malas, nakal, & \\
pandai, rapi, sahaja, tegas, ulet, wibawa, ... & picik, rakus, sakit, takut, ... & \\
\hline
\end{tabular}

Setelah melalui proses perhitungan interval polaritas, data tweet akan digunakan sebagai training set untuk proses machine learning. Machine learning-based adalah metode pendekatan menggunakan algoritma pembelajaran seperti Naive Bayes (NB), J48, Support Vector Machine (SVM), dan lain sebagainya. Metode ini sering digunakan untuk klasifikasi teks dan dapat menunjukkan efektivitasnya ketika diterapkan pada permasalahan SA. Pendekatan ini memerlukan training set untuk pembentukan model klasifikasi dan kemudian dibandingkan dengan data baru yang belum terlabelkan atau disebut test set untuk diklasifikasikan (Drucker, dkk., 1999). Hal ini penting dilakukan untuk mengevaluasi kemampuan generalisasi dari algoritma terhadap data baru dan keakuratan mengklasifikasikan. Biasanya, pelabelan training set membutuhkan banyak waktu dan tenaga apabila dibuat secara manual, dan sangat tergantung pada persepsi masing-masing individu (Lima, dkk., 2015). Adanya keterbatasan tersebut, digunakan model hybrid yaitu menggunakan alat bantu lexical database sebagai pelabelan secara otomatis data tweet untuk pembentukan training set pada machine learning-based. Pada penelitian ini digunakan algoritma klasifikasi J48 (Thelwall, dkk., 2010) untuk mendeteksi sentimen setiap tweet. Dari setiap dokumen training diekstraksi term-nya dan diberikan bobot, kemudian term tersebut ditetapkan sebagai kata kunci untuk setiap kategori sentimen (Li \& Xu, 2014).

Langkah berikutnya, data timestamp saat mem-posting tweet dari tiap akun Twitter dikumpulkan dan dicari interval waktunya. TIE digunakan untuk menangkap pola keteraturan waktu posting tweet yang menunjukkan otomatisasi. TIE $(H)$ dihitung dengan menggunakan persamaan (1) dan persamaan (2) (Chu, dkk., 2012). $\Delta$ T merepresentasikan interval waktu antar tweet, dimana $P \Delta \mathrm{T}\left(\Delta \mathrm{t}_{\mathrm{i}}\right)$ menunjukkan probabilitas interval waktu $\Delta \mathrm{T}_{\mathrm{i}}$. Komponen entropy dapat mendeteksi waktu periodik yang merupakan indikasi kuat kejadian otomatisasi. Pengguna twitter yang memiliki entropy lebih rendah dari threshold akan diklasifikasikan sebagai bot spammer karena nilai entropi rendah dibawah threshold menunjukkan perilaku yang teratur. Terakhir, kedua nilai SA dan TIE digabungkan menggunakan persamaan (3) untuk mengklasifikasikan setiap akun pengguna Twitter ke dalam kelasnya.

$$
\begin{aligned}
& H_{\Delta T}(T i)=-\sum_{i=1}^{n T} P \Delta T\left(\Delta t_{i}\right) \log \left(P \Delta T\left(\Delta t_{i}\right)\right) \\
& P \Delta T\left(\Delta t_{i}\right)=\frac{n \Delta t_{i}}{\sum_{k=1}^{n T} n \Delta t_{k}} \\
& \text { Score }_{k}=\frac{\alpha\left(1-H_{k}\right)+\beta(\operatorname{san})}{\alpha\left(\max \left(1-H_{k}\right)\right)+\beta\left(\max \left(s a_{k}\right)\right]}
\end{aligned}
$$

Untuk setiap akun pengguna Twitter $k$, nilai perhitungan SA dan TIE dikalikan dengan faktor pembobotan untuk mengambil nilai akhir. Variabel $\alpha$ dan $\beta$ masing-masing menunjukkan faktor pembobotan dari SA dan TIE. Jumlah dari kedua faktor pembobotan variabel bernilai 1 (Perdana, dkk., 2015). 


\section{Hasil dan Diskusi}

Untuk melakukan evaluasi kinerja metode yang diusulkan secara kuantitatif, digunakan perhitungan precision dan recall. Precision adalah jumlah kelompok dokumen relevan dari total jumlah dokumen yang ditemukan oleh sistem. Sedangkan, recall diartikan sebagai jumlah dokumen relevan yang ditemukan oleh sistem. Precision dan recall dapat dilihat pada persamaan (4) dan persamaan (5).

$$
\begin{aligned}
& \text { Precision }=\frac{T P}{T P+F P} \\
& \text { Recall }=\frac{T P}{T P+F N}
\end{aligned}
$$

Perhitungan precision dan recall menggunakan kombinasi True Positive (TP), False Positive (FP), dan False Negative (FN). Dalam penelitian ini, TP mengacu pada jumlah akun yang diklasifikasikan dengan benar sebagai bot spammer. FP merupakan jumlah akun legitimate user yang diklasifikasikan tidak benar sebagai bot spammer. Sedangkan FN adalah bot spammer yang tidak tepat diklasifikasikan sebagai akun legitimate user. Penentuan nilai threshold pada tiap skenario uji coba berbeda, hal ini berdasarkan beberapa kali percobaan untuk pencarian hasil precision dan recall terbaik.

Pada uji coba pertama menggunakan fitur SA, jika user memliki nilai sentimen diatas batas threshold 0,5, user tersebut diklasifikasikan sebagai bot spammer. Hasil uji coba pertama dapat dilihat pada Tabel 3. Pada Tabel 3, terdapat beberapa user yang tidak tepat terklasifikasikan sesuai groundtruth. Pada user nomor 3 yang seharusnya terklasifikasikan sebagai spam namun oleh sistem mendapat nilai dibawah threshold, hal ini disebabkan karakteristik user tersebut cukup mirip dengan legitimate user dimana menggunakan beberapa kata yang terindikasi memiliki sentimen. Selain itu beberapa pengguna Twitter sering menggunakan singkatan kata, bahasa campuran selain Bahasa Indonesia dan penggunaan kata yang tidak sesuai Ejaan Yang Disempurnakan (EYD), dimana dapat menyulitkan fitur yang diambil serta mengurangi ketepatan klasifikasi. Untuk nilai precision dan recall penggunaan fitur SA secara berurutan adalah $82 \%$ dan $82 \%$.

Untuk uji coba kedua menggunakan fitur TIE, hasil uji coba terlampir pada Tabel 4, terdapat beberapa akun legitimate user tidak tepat terklasifikasikan sebagai bot spammer, hal ini mengindikasikan bahwa beberapa perilaku legitimate user sering memiliki pola keteraturan interval waktu yang sama dengan bot spammer dalam memposting tweet. Beberapa contoh akun twitter yang tidak tepat terklasifikasi dengan menggunakan fitur TIE adalah akun berjenis media berita, dimana akun media berita seringkali mem-posting tweet secara teratur sesuai jadwal meskipun tanpa menggunakan robot ataupun aplikasi yang secara otomatis. Dengan demikian, penggunaan fitur TIE juga tidak cukup optimal untuk membedakan legitimate user dan bot spammer dengan nilai precision dan recall secara berurutan adalah $75 \%$ dan $82 \%$.

Pada uji coba ketiga, dilakukan penggabungan kedua fitur SA dan TIE dengan penggunaan bobot rasio perbandingan $\alpha$ dan $\beta$ bernilai 1:1 dengan nilai precision dan recall secara berurutan $83 \%$ dan $91 \%$. Berikut terlampir hasil uji coba ketiga pada Tabel 5.

Berdasarkan hasil yang telah dipaparkan metode yang diusulkan memiliki nilai precision sebesar $83.00 \%$ dan recall sebesar $91 \%$. Perbandingan dari hasil uji coba semua metode dapat dilihat pada Gambar 2 dimana terdapat perbandingan nilai precision dan recall. Dari Gambar 2 dapat dilihat bahwa penggunaan gabungan fitur SA+TIE dapat mengoptimalkan nilai precision dan recall dibanding kedua uji coba sebelumnya yang mengindikasikan bahwa kedua fitur dapat saling terintegrasi dan menutupi kekurangan dari penggunaan satu fitur, SA atau TIE. 
Tabel 3. Hasil klasifikasi sistem menggunakan SA.

\begin{tabular}{cccc}
\hline $\begin{array}{c}\text { User } \\
\text { ID }\end{array}$ & Nilai & Class & $\begin{array}{c}\text { Ground } \\
\text { truth }\end{array}$ \\
\hline $\mathbf{1}$ & 0,12 & $\mathrm{~L}$ & Spam \\
$\mathbf{2}$ & 0,19 & $\mathrm{~L}$ & $\mathrm{~L}$ \\
$\mathbf{3}$ & 0,21 & $\mathrm{~L}$ & Spam \\
$\mathbf{4}$ & 0,96 & $\mathrm{~S}$ & $\mathrm{~S}$ \\
$\mathbf{5}$ & 0,92 & $\mathrm{~S}$ & $\mathrm{~S}$ \\
$\mathbf{6}$ & 0,87 & $\mathrm{~S}$ & $\mathrm{~S}$ \\
$\mathbf{7}$ & 0,79 & $\mathrm{~S}$ & $\mathrm{~S}$ \\
$\mathbf{8}$ & 0,62 & $\mathrm{~S}$ & $\mathrm{~L}$ \\
$\mathbf{9}$ & 0,91 & $\mathrm{~S}$ & $\mathrm{~S}$ \\
$\mathbf{1 0}$ & 0,13 & $\mathrm{~L}$ & $\mathrm{~L}$ \\
$\mathbf{1 1}$ & 0,71 & $\mathrm{~S}$ & $\mathrm{~S}$ \\
$\mathbf{1 2}$ & 0,98 & $\mathrm{~S}$ & $\mathrm{~S}$ \\
$\mathbf{1 3}$ & 0,89 & $\mathrm{~S}$ & $\mathrm{~S}$ \\
$\mathbf{1 4}$ & 0,93 & $\mathrm{~S}$ & $\mathrm{~S}$ \\
$\mathbf{1 5}$ & 0,37 & $\mathrm{~L}$ & $\mathrm{~L}$ \\
$\mathbf{1 6}$ & 0,57 & $\mathrm{~S}$ & $\mathrm{~L}$ \\
$\mathbf{1 7}$ & 0,42 & $\mathrm{~L}$ & $\mathrm{~S}$ \\
$\mathbf{1 8}$ & 0,39 & $\mathrm{~L}$ & $\mathrm{~S}$ \\
\hline Threshold : 0,5 & & \\
\hline L: Legitimate, S: Spam &
\end{tabular}

Tabel 4. Hasil klasifikasi sistem menggunakan TIE

\begin{tabular}{cccc}
\hline $\begin{array}{c}\text { User } \\
\text { ID }\end{array}$ & Nilai & Class & $\begin{array}{c}\text { Ground } \\
\text { truth }\end{array}$ \\
\hline $\mathbf{1}$ & 0,62 & $\mathrm{~S}$ & $\mathrm{~S}$ \\
$\mathbf{2}$ & 0,71 & $\mathrm{~L}$ & $\mathrm{~L}$ \\
$\mathbf{3}$ & 0,69 & $\mathrm{~L}$ & $\mathrm{~S}$ \\
$\mathbf{4}$ & 0,03 & $\mathrm{~S}$ & $\mathrm{~S}$ \\
$\mathbf{5}$ & 0,02 & $\mathrm{~S}$ & $\mathrm{~S}$ \\
$\mathbf{6}$ & 0,02 & $\mathrm{~S}$ & $\mathrm{~S}$ \\
$\mathbf{7}$ & 0,22 & $\mathrm{~S}$ & $\mathrm{~S}$ \\
$\mathbf{8}$ & 0,04 & $\mathrm{~S}$ & $\mathrm{~L}$ \\
$\mathbf{9}$ & 0,21 & $\mathrm{~S}$ & $\mathrm{~S}$ \\
$\mathbf{1 0}$ & 0,51 & $\mathrm{~L}$ & $\mathrm{~L}$ \\
$\mathbf{1 1}$ & 0,02 & $\mathrm{~S}$ & $\mathrm{~S}$ \\
$\mathbf{1 2}$ & 0,01 & $\mathrm{~S}$ & $\mathrm{~S}$ \\
$\mathbf{1 3}$ & 0,02 & $\mathrm{~S}$ & $\mathrm{~S}$ \\
$\mathbf{1 4}$ & 0,02 & $\mathrm{~S}$ & $\mathrm{~S}$ \\
$\mathbf{1 5}$ & 0,30 & $\mathrm{~S}$ & $\mathrm{~L}$ \\
$\mathbf{1 6}$ & 0,29 & $\mathrm{~S}$ & $\mathrm{~L}$ \\
$\mathbf{1 7}$ & 0,02 & $\mathrm{~S}$ & $\mathrm{~S}$ \\
$\mathbf{1 8}$ & 0,51 & $\mathrm{~L}$ & $\mathrm{~S}$ \\
\hline Threshold $: 0,3461$ & \\
\hline
\end{tabular}

Tabel 5. Hasil klasifikasi sistem menggunakan SA dan TIE

\begin{tabular}{cccc}
\hline $\begin{array}{c}\text { User } \\
\text { ID }\end{array}$ & Nilai & Class & $\begin{array}{c}\text { Ground } \\
\text { truth }\end{array}$ \\
\hline $\mathbf{1}$ & 0,26 & $\mathrm{~S}$ & $\mathrm{~S}$ \\
$\mathbf{2}$ & 0,25 & $\mathrm{~L}$ & $\mathrm{~L}$ \\
$\mathbf{3}$ & 0,27 & $\mathrm{~L}$ & $\mathrm{~S}$ \\
$\mathbf{4}$ & 0,99 & $\mathrm{~S}$ & $\mathrm{~S}$ \\
$\mathbf{5}$ & 0,98 & $\mathrm{~S}$ & $\mathrm{~S}$ \\
$\mathbf{6}$ & 0,95 & $\mathrm{~S}$ & $\mathrm{~S}$ \\
$\mathbf{7}$ & 0,81 & $\mathrm{~S}$ & $\mathrm{~S}$ \\
$\mathbf{8}$ & 0,81 & $\mathrm{~S}$ & $\mathrm{~L}$ \\
$\mathbf{9}$ & 0,86 & $\mathrm{~S}$ & $\mathrm{~S}$ \\
$\mathbf{1 0}$ & 0,32 & $\mathrm{~L}$ & $\mathrm{~L}$ \\
$\mathbf{1 1}$ & 0,87 & $\mathrm{~S}$ & $\mathrm{~S}$ \\
$\mathbf{1 2}$ & 0,99 & $\mathrm{~S}$ & $\mathrm{~S}$ \\
$\mathbf{1 3}$ & 0,96 & $\mathrm{~S}$ & $\mathrm{~S}$ \\
$\mathbf{1 4}$ & 0,98 & $\mathrm{~S}$ & $\mathrm{~S}$ \\
$\mathbf{1 5}$ & 0,55 & $\mathrm{~L}$ & $\mathrm{~L}$ \\
$\mathbf{1 6}$ & 0,65 & $\mathrm{~S}$ & $\mathrm{~L}$ \\
$\mathbf{1 7}$ & 0,72 & $\mathrm{~S}$ & $\mathrm{~S}$ \\
$\mathbf{1 8}$ & 0,45 & $\mathrm{~L}$ & $\mathrm{~S}$ \\
\hline Threshold $: \mathbf{0 , 6}$ & & \\
\hline
\end{tabular}

Evaluasi Performa

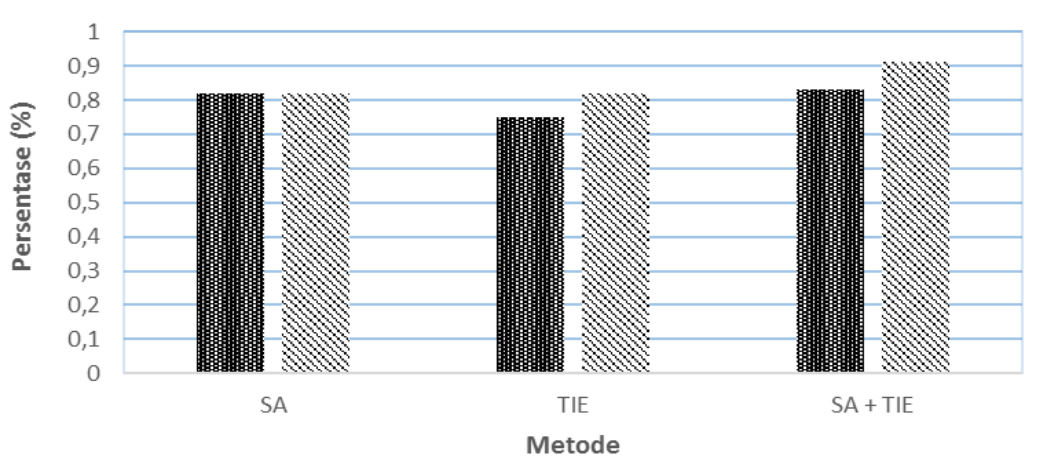

Precision \$Recall

Gambar 2. Perbandingan evaluasi performa SA, TIE, dan SA + TIE

\section{Kesimpulan}

Dalam penelitian ini telah diusulkan metode baru untuk membedakan antara bot spammer dan legitimate user dengan mengintegrasikan SA yang berdasarkan emosi dan TIE. Sentiment analysis (SA) digunakan untuk mendeteksi ungkapan ekspresi ataupun opini yang terkandung dalam tweet. Sedangkan TIE digunakan untuk menangkap keteraturan waktu memposting tweet yang menunjukkan tweet diunggah secara otomatis.

Serangkaian percobaan telah dilakukan untuk mengevaluasi kinerja dari metode yang diusulkan. Dari hasil eksperimen dapat disimpulkan bahwa penggabungan SA dan TIE dapat mengoptimalkan performa sistem secara keseluruhan dalam mengidentifikasi bot spammer dengan nilai precision dan recall masing-masing $83 \%$ dan $91 \%$.

Penelitian lebih lanjut dapat dilakukan untuk menyelidiki hubungan semantik pada tweet dimana kata dapat mengalami bias atau bermakna ganda. Selain itu dalam pendeteksian bot spammer dapat juga ditambahkan beberapa karakterisktik seperti jumlah follower, following, dan retweet. Beberapa bot spammer secara otomatis mengikuti legitimate user dan juga melakukan retweet secara otomatis terhadap tweet yang mencakup kata atau frase tertentu.

\section{Referensi}

Arifin, A. Z., \& Setiono, A. N. 2002. Klasifikasi Dokumen Berita Kejadian Berbahasa Indonesia dengan Algoritma Single Pass Clustering. In Prosiding Seminar on Intelligent 
Technology and its Applications (SITIA), Teknik Elektro, Institut Teknologi Sepuluh Nopember Surabaya.

Chu, Z., Gianvecchio, S., Wang, H., \& Jajodia, S. 2012. Detecting automation of twitter accounts: Are you a human, bot, or cyborg?. Dependable and Secure Computing, IEEE Transactions on, 9(6), 811-824.

Drucker, H., Wu, D., \& Vapnik, V. N. 1999. Support vector machines for spam categorization. Neural Networks, IEEE Transactions on, 10(5), 1048-1054.

Esuli, A., \& Sebastiani, F. 2006. Sentiwordnet: A publicly available lexical resource for opinion mining. In Proceedings of LREC (Vol. 6, pp. 417-422).

Heron, S. 2009. Technologies for spam detection. Network Security, 2009(1), 11-15.

Hu, M., \& Liu, B. 2004. Mining and summarizing customer reviews. In Proceedings of the tenth ACM SIGKDD international conference on Knowledge discovery and data mining (pp. 168-177). ACM.

Kontopoulos, E., Berberidis, C., Dergiades, T., \& Bassiliades, N. 2013. Ontology-based sentiment analysis of twitter posts. Expert systems with applications, 40(10), 40654074 .

Li, W., \& Xu, H. 2014. Text-based emotion classification using emotion cause extraction. Expert Systems with Applications, 41(4), 1742-1749.

Lima, A. C. E., de Castro, L. N., \& Corchado, J. M. 2015. A polarity analysis framework for Twitter messages. Applied Mathematics and Computation, 270, 756-767.

Liu, B. 2012. Sentiment analysis and opinion mining. Synthesis lectures on human language technologies, 5(1), 1-167.

Miller, Z., Dickinson, B., Deitrick, W., Hu, W., \& Wang, A. H. 2014. Twitter spammer detection using data stream clustering. Information Sciences, 260, 64-73.

Mohammad, S. M., Zhu, X., Kiritchenko, S., \& Martin, J. 2014. Sentiment, emotion, purpose, and style in electoral tweets. Information Processing \& Management. Elsevier.

Montejo-Ráez, A., Martínez-Cámara, E., Martín-Valdivia, M. T., \& Ureña-López, L. A. 2014. Ranked wordnet graph for sentiment polarity classification in twitter. Computer Speech \& Language, 28(1), 93-107.

Moraes, R., Valiati, J. F., \& Neto, W. P. G. 2013. Document-level sentiment classification: An empirical comparison between SVM and ANN. Expert Systems with Applications, 40(2), 621-633.

Perdana, R. S., Muliawati, T. H., \& Alexandro, R. 2015. Bot Spammer Detection in Twitter Using Tweet Similarity And Time Interval Entropy. Jurnal Ilmu Komputer dan Informasi, 8(1), 20-26.

Poria, S., Cambria, E., Winterstein, G., \& Huang, G. B. 2014. Sentic patterns: Dependencybased rules for concept-level sentiment analysis. Knowledge-Based Systems, 69, 45-63.

Takhteyev, Y., Gruzd, A., \& Wellman, B. 2012. Geography of Twitter networks. Social networks, 34(1), 73-81.

Tala, F. Z. 2003. A study of stemming effects on information retrieval in Bahasa Indonesia. Institute for Logic, Language and Computation Universeit Van Amsterdam.

Tausczik, Y. R., \& Pennebaker, J. W.(2010. The psychological meaning of words: LIWC and computerized text analysis methods. Journal of language and social psychology, 29(1), 24-54.

Thelwall, M., Buckley, K., Paltoglou, G., Cai, D., \& Kappas, A. 2010. Sentiment strength detection in short informal text. Journal of the American Society for Information Science and Technology, 61(12), 2544-2558.

Verma, M., \& Sofat, S. 2014. Techniques to Detect Spammers in Twitter-A Survey. International Journal of Computer Applications, 85(10), 27-32.

Yang, C., Harkreader, R. C., \& Gu, G. 2011. Die free or live hard? empirical evaluation and new design for fighting evolving twitter spammers. InRecent Advances in Intrusion Detection (pp. 318-337). Springer Berlin Heidelberg. 